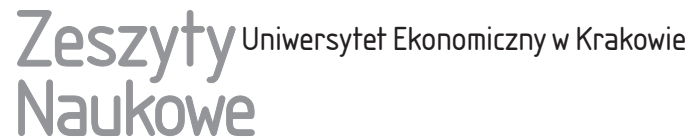

\section{The Use of Blockchain Technology in Agriculture}

\begin{abstract}
Objective: This paper explores the use of blockchain technology in agriculture and agricultural products.

Research Design \& Methods: The article is based on a critical analysis of the literature with a view to understanding the current state of use of blockchain technology in agriculture. It was assumed that blockchain technology is used in the agricultural sector to promote food security, prevent food fraud and verify the origin and authenticity of agricultural products and agricultural inputs.

Findings: Blockchain technology improves traceability and transparency, allowing parties within the agricultural value chain to identify faulty or suboptimal processes as well as bad actors. This ensures that ideal conditions are pursued from farm to market. The ability to trace the origin of food products is essential when food safety breaks down. The early identification of the origin of contamination will enable food companies to swing into action quickly to prevent illness and thus save lives. Such a timely response will also help limit food wastage and will save money by containing financial fallout.

Implications / Recommendations: Blockchain technology has strong potential for success within the agricultural sector. It can be used to ensure food safety by enabling the source of agricultural products, as well as the source of their potential contamination, to be traced, and the authenticity of farming inputs to be verified. Blockchain can also be
\end{abstract}

Mustafa Cem Aldag, Bandırma Onyedi Eylül University, Merkez Yerleşkesi 10200 Bandırma, Balikesir, Turkey, e-mail: maldag@bandirma.edu.tr, ORCID: https://orcid.org/0000-00017224-2277.

This is an open access article distributed under the terms of the Creative Commons Attribution-NonCommercial-NoDerivatives 4.0 License (CC BY-NC-ND 4.0); https://creativecommons.org/ licenses/by-nc-nd/4.0/ 
employed in the process of disbursing subsidies to farmers to ensure that they benefit from subsidy programmes. Finally, blockchain technology will offer farmers better prices and better payment methods and solve challenges in land title sales and purchase registration. Contribution: Blockchain is a new technology to the agricultural sector, and enormous challenges remain. There is still no established system to regulate blockchain transactions. Nevertheless, the application of blockchain in agriculture holds promising rewards.

Keywords: blockchain, agriculture, food fraud, food safety.

JEL Classification: Q16.

\section{Introduction}

Blockchain technology is part of industry 4.0, which encompasses automation and data exchange in production processes. Industry 4.0 integrates the internet of things (IoT), cyber-physical systems, cognitive computing and cloud computing. Blockchain technology is gaining in popularity alongside cryptocurrencies such as Bitcoin. Even though the first use of blockchain was in cryptocurrencies, the technology holds great potential for other types of transactions. This paper explores the use of block technology in agriculture and agricultural products.

Blockchain is a modern technology used in business transactions. At root, it consists of structured data holding transactional records, and at the same time ensures transparency, security, and decentralisation. Satoshi Nakamoto first applied blockchain technology in 2009, creating a Bitcoin or digitized currency which can be traded in the place of fiat capital. Transactions done with blockchain technology are secured with a digital, encrypted, tamper-proof signature, making them very difficult to change. Blockchain makes financial transactions possible while removing the need for intermediaries such as banks. However, blockchain has been used for other purposes in agriculture, including supporting small scale farmers and the evolution of ICT E-Agriculture as well as ensuring food security and safety.

\section{The Role of Blockchain in Agriculture}

Blockchain can be used to ensure food safety within the agricultural supply chain by improving traceability and transparency, allowing parties within the agricultural value chain to identify poor or faulty processes as well as bad actors (Tian 2017). This ensures that the best conditions possible are maintained from the farms up to the market. The ability to trace the origin of food products becomes important when there is a breakdown in or threat to food safety. Employing blockchain, industry regulators can quickly pinpoint the source of the contaminant as 
well as determine the scope of the affected products (Underwood 2016). The early identification of the origin of contamination will enable food companies to swing into action quickly to prevent illness and thus save lives. Such a timely response will also help limit food wastage and will save money by containing the financial fallout. There is already clear vested interest from both producers and consumers, and companies such as IBM and Walmart have begun work in the area of food safety by employing blockchain technology.

Food security has been defined as the ability of an individual, at all times, to have financial, physical, and social access to safe, sufficient, and nutritious food, meeting their desire for particular quality and the preferences of food for a life that is active and healthy. Achieving such goals has been limited by various humanitarian disasters including environmental calamities as well as ethnic and political conflict. Blockchain technology has gained success where its workability has been affirmed with the use of cryptocurrency; hence, different agricultural organisations are using the technology to harness its transparency (De Fazio 2016). That clarity can help solve challenges that accompany intermediaries that hinder the distribution of resources and financial transactions. Agriculture and the supply chain are essential areas in terms of both products and the cultivation of the acres.

Agriculture is connected to the food suppy chain, with the end products necessary as inputs in multi-actor supply chain distributions. Along the supply chain, consumers are the end clients (Ge et al.2017). Blockchain can be used in many sectors. One of them is international aid. The technology can be used to track donations and make them more secure. People do purchase goods locally and hence are unaware of their origin or the production footprints (Kamilaris, Prenafeta-Boldú \& Fonts 2018). Due to this lack of awareness, when issues related to the buying and supplying of the food erupts, blockchain technology can offer a solution, hence solving real-life problems that crop up in the agricultural supply chain.

When a product is traceable, both retailers and consumers will trust it more. If the entire supply chain for agricultural products is embedded in a blockchain-driven ecosystem, from product registration and payment to transport and delivery, then retailers can verify that the product they are receiving is what they paid for. Since every step of the transaction process is recorded in the blockchain, any claim by a supplier about the origins of his products can be confirmed by tracing the journey of the product from the farmer up to the point it was received at the shop, thus alleviating concerns of misrepresentation. A transparently distributed ledger will increase consumer confidence in the origins of their food as well as the efficiency of its production (Lemieux 2016). In monitoring their food chain, consumers 
will be better informed of the origin of their food, their dates of its manufacture and the efficiency with which products are created.

Startups such as Provenance are already using blockchain to provide concrete proof of the origin of their food supplies. Derivation uses blockchain to secure and keep track of its food supply chains and make such information public, thus ensuring the process is inclusive of all partners in the supply chain (Kim \& Laskowski 2018). Provenance uses the ledger to comprehensively document ingredients, supply chain materials, and products, thus giving their customers greater transparency about the authenticity and origin of their products. The startup provides buyers with a fully transparent record in the format of a real-time data platform. This allows the buyers to see each step in the product's journey from the current location of the product, the current owner, and the period the product was with a particular person.

\section{Findings}

Despite the limitations blockchain technology is experiencing, including the transformation of Information Communication and Technology (ICT), the trust people had in mistrusted parties in financial transactions has changed. Intermediary parties such as banks are no longer required when transacting money thanks to the blockchain technology they have in place. Similarly, blockchain is being used to develop greater efficiency in agriculture as ICT has enabled access to knowledge about banks and digital resources. Blockchain technology has provided sufficient infrastructure in e-agriculture, regarding ICT's potential, formulation of priorities, and aims as a crucial first step (Yu-Pin Lin et al. 2017). For several decades, initiatives for monitoring agricultural environments have embraced a wide range of ICT. This includes technologies for long-distance monitoring of farmland conditions and managing equipment with smartphone applications. Agricultural systems that help in monitoring environments support both timeless deterrent systems and baseline measuring of data that can be used by managers in planning (Prasannan, Vargese \& Smita 2019).

At the same time, the availability of the blockchain, environmental, and agricultural data, monitored and kept in a dispensable cloud, creates a space for trust, thus securing sustainable agricultural development using ICT and free, transparent data. Blockchain technology, as it is interlinked with crypto-economic security, ensure all data recorded at the national level adheres to international agricultural standards and the naming of conventions that may remain unreachable to malicious attackers (Yu-Pin Lin et al. 2017). Indeed, agrarian networks making use of blockchain are decentralized and immutable systems with groundbreaking 
control. The immutability can revolutionise all resources that are biophysically documented, captured from sources used, and reused in a wide-range data set.

The traceability and accompanying transparency offered by blockchain models play a crucial role in preventing food fraud, which occurs mostly through false labeling. As the demand for antibiotic-free, organic, and GMO food soars, fraudulent labeling is becoming common. However, blockchain technology and the internet of things are used to efficiently monitor the entire supply chain. Even the smallest transactions occurring at the warehouse, farm, or factory can be monitored by IoT technologies such as RFID tags and sensors, with the information then communicated across the supply chain (Tian 2016). Blockchain will thus save giant shipping companies millions by ensuring efficiency and reducing the incidence of fraud occurring anywhere in the hundreds of interactions involved in supply chains.

Blockchain technology reduces transaction costs and leads to fair pricing. It also enables commodity buyers to deal directly with their suppliers and make payments through mobile transfer. Buyers and suppliers will thus find it easier to negotiate fair prices for their agricultural products. The farmer will receive a reasonable amount for their agricultural produce, and the retailer will equally pay a fair price for the agricultural products supplied. The retailer saves money because the technology eliminates agents and middlemen. Blockchain technology ultimately allows the farmers and producers to justify the premiums they set for certain agricultural products (Ge et al. 2017). Block technology will also help reduce transaction costs brought by the heavily fragmented market for farm products.

The demand for agricultural goods is heavily dependent on personally knowing a party along the supply chain before one can trust them to do business. The trust and accountability created by the ledger that is available to all parties can reduce or even eliminate the need to evaluate each party individually on their trustworthiness and their ability to execute a deal. Those who deal in agricultural goods can, therefore, do business without the need to broker trust.

Food safety encompasses how food is prepared, handled and stored for consumption, and is key to consumers not being made ill (Ray et al. 2019). To avoid that, digitisation should provide information that is trustworthy and reliable as concerns the source of a food product. At the same time, traceability can enhance food safety, with the appropriate department able to step in to ascertain the cause of challenges facing food production (Yu-Pin Lin et al. 2017). Using blockchain, food organisations can locate outbreaks by tracing particular sources, and thereby reduce the theft of food. Blockchain technology may be used to track goods moving from one destination to another down the supply chain and overseas (Allen et al.2019). Many food organisations are embracing blockchain to enhance 
food integrity and safety. In 2006, Oceana carried out research on deceitful practices in the seafood industry and concluded that twenty percent of seafood is mislabeled. Blockchain technology can be used in tracing the originality of such cases. This is done with the help of an application in a decentralized cloud to solve the problems (Fernández-Caramés \& Fraga-Lamas 2018).

Additionally, other researchers have noted that food supply chains earn little trust, while quality and complexity require long-distance shipping and have long procedural times. Here too blockchain can help, by providing an effective solution where advanced traceability of food is achieved based on increased transparency and safety. At the same time, problems surrounding food safety should be identified and authorities notified quickly.

For entities involved in agri-commerce, the application of blockchain technology will help provide faster payment options at reduced costs. Across the globe, farmers experience a massive delay in the release of funds for their produce submitted to various national agricultural boards. Adding to the farmer's misery is the costly nature of payment options, such as wire transfers. Some of these inefficiencies can be solved by blockchain. There are already blockchain-based apps designed by some developers to peer fund transfers that are secure, near-instantaneous, and cheap (Chinaka 2016). By using smart contracts, payments are automatically triggered as soon as the buyer confirms the fulfillment of certain conditions.

\section{Recommendations}

Blockchain technology can also be used to verify the authenticity of agricultural inputs. More often than not, farmers are not sure if the contributions they buy are authentic. Local retailers likewise sell fake products to farmers, raking in huge profits as a result. Sometimes the retailers themselves may not know if the products they purchase from their suppliers are authentic. Even large companies that produce agricultural inputs are losing millions of dollars as a result of duplication or pilferage, which also negatively affects the companies' brand image. Blockchain may be a solution to this problem as it will increase the traceability of each input sold, from the manufacturer to the last buyer. Blockchain will also make it possible for farmers and retailers to check the authenticity and origin of the inputs they buy. All they need to do is scan the blockchain barcode on each product with a smartphone (Crosby et al. 2016).

Yet another area of application for blockchain is agriculture island title registration. Globally, the process of registering the sale or purchase of land is often complicated and highly susceptible to fraud. Land cartels corrupt the land regis- 
tration process, making it difficult for buyers to know if the land they are buying or leasing is litigation free. Blockchain can make the recording of property transactions more efficient and, because the recorded data is accessible and publicly available, more transparent as well (Chavez-Dreyfuss 2016). Blockchain is already being used in land registration, with one of the first movers in this space being Andhra Pradesh. Pradesh has partnered with ChromaWay, a startup from Sweden Blockchain, to build a blockchain solution for land registration and recordkeeping (Anand, McKibbin \& Pichel 2017). Record keeping requires significant labour and financial outlays, and blockchain is expected to reduce both. Moreover, with smart contracting between farmers and corporate farming firms, contracting for leasing land will become easier. Ethereum is an example of a blockchain project built to realise the potential of intelligent contracting.

Supporting small scale farmers and the emerging cooperatives is one essential way to both impart and boost efficiency in less developed nations. Organisations should be able to portray technology to the future generations using digitized networks to supply small scale products for supporting them (Chang et al. 2018). Other cooperatives established by the farmers use a method that actively raises competition in less developed countries, thereby assisting farmers with a chance of winning a large number of shares on the crops they are farming. AgriLedger works through a mobile app, which helps record truth that, thanks to blockchain, is incorruptible. Small-scale farmers can use a distributed crypto ledger and mobile apps to create trusted circles. OlivaCoin, a B2B, provides platform that supports the trading of olive oil with a view to enhancing the reduction of capital costs overall and maximizing transparency, hence speeding up access to global markets (Kamilaris, Prenafeta-Boldú \& Fonts 2018). Start-ups including Arc Net, Bext 360, provenance, and Bart Digital provide provide small farm cultivators with tools and thus swift traceability in a growing number of products.

Additionally, small-scale farmers may benefit from blockchain technology when they focus on carving out niches separate from major corporations. Currently, blockchain is swiftly gaining acceptance at major mainstream firms, suggesting the roles and uses of analyzing data will grow (Elizur 2018). Thus, the small-scale farmers are advised to begin maximising their options and to get in the game. Ultimately, cooperatives can include either small or medium farmers and grow into big entities capable of satisfying consumers; all these can be achieved with the use of blockchain technology, which aids in peacefully resolving disputes and feuds between farmers and cooperatives.

Across the globe, agriculture relies heavily on government subsidies, though how much of the subsidies actually reach farmers is an open question. Much of the money is grabbed up by cartels who purchase large quantities of agricultural inputs such as fertilisers, then exhaust the stock in order to force farmers to buy 
their inputs from the cartels. The application of blockchain will, however, improve transparency in the distribution and delivery of subsidies. This will ensure that the targeted disbursement of grants will reach local farmers and help reduce the theft and corruption in the system (Swan 2015). Establishing such a network is a complex process that calls for multiple stakeholders to come together, but that is not impossible with today's technology.

\section{Conclusion}

Blockchain has become a modest technology that is used in financial business transactions. Structured data records held in blockchain are seen as secure, decentralised, and transparent. Data kept in a blockchain is digitally recorded and has a history that is standard and available to each user of the network. A digitised signature is used to secure the information stored on each blockchain, while network nodes validate every transaction that transpires on a blockchain. Blockchain technology has proved that technological advances in agriculture provide a solution to the crisis that has embroiled food production and human food consumption. Blockchain plays a critical role in food security, food safety, support for small-scale farmers and the evolution of CTI E-Agriculture.

Blockchain technology has strong potential for success in agriculture. It can help ensure food safety by making it possible to trace the source of contamination. It can also be used to trace the origin of an agricultural product and to verify the authenticity of farming inputs. Blockchain can also be employed in the disbursement of subsidies to farmers to ensure that they benefit from such programmes. Blockchain technology will bring better prices and better payment methods to farming as well as solve challenges in land title sales and purchase registration. Blockchain is still in a relatively nascent stage, especially in the agricultural sector, and the challenges that remain are enormous. One of these challenges concerns regulation across the globe, as there is still no established system to regulate blockchain transactions. Nevertheless, the application of blockchain in agriculture holds promising rewards.

\section{Acknowledgment}

This work was supported by the Scientific Research Projects Coordination Unit of Bandirma Onyedi Eylül University BAP-18-REKT-1009-079. 


\section{Bibliography}

Allen D. W. E., Berg Ch., Davidson S., Novak M., Potts J. (2019), International Policy Coordination for Blockchain Supply Chains, "Asia and the Pacific Policy Studies", May, https://doi.org/10.1002/app5.281.

Anand A., McKibbin M., Pichel F. (2017), Colored Coins: Bitcoin, Blockchain, and Land Administration, 24 March, https://cadasta.org/resources/white-papers/bitcoin-blockchain-land/ (accessed: 24 November 2019).

Chang J., Katehakis M. N., Melamed B., Shi J. (2018), Blockchain Design for Supply Chain Management, "SSRN Solutions", 27 December, https://papers.ssrn.com/ sol3/papers.cfm?abstract_id=3295440 (accessed: 24 November 2019), https://doi. org/10.2139/ssrn.3295440.

Chavez-Dreyfuss G. (2016), Sweden Tests Blockchain Technology for Land Registry, June 16, https://www.reuters.com/article/us-sweden-blockchain/sweden-tests-blockchain-technology-for-land-registry-idUSKCN0Z22KV (accessed: 24 November 2019).

Chinaka M. (2016), Blockchain Technology - Applications in Improving Financial Inclusion in Developing Economies: Case Study for Small Scale Agriculture in Africa, "Research Gate Journal".

Crosby M., Nachiappan, Pattanayak P., Verma S., Kalyanaraman V. (2016), BlockChain Technology: Beyond Bitcoin, "AIR Applied Innovation Review", no 2.

De Fazio M. (2016), Agriculture and Sustainability of the Welfare: The Role of the Short Supply Chain, "Agriculture and Agricultural Science Procedia", vol. 8, https://doi. org/10.1016/j.aaspro.2016.02.044.

Elizur I. (2018), How to Use Blockchain and Big Data for Better Small Business Profits, 26 December, https://smallbiztrends.com/2018/02/big-data-blockchain-small-business. html (accessed: 24 November 2019).

Fernández-Caramés T. M., Fraga-Lamas P. (2017), A Review on the Use of Blockchain for the Internet of Things, "IEEE Access", vol. 6, https://doi.org/10.1109/ ACCESS.2018.2842685.

Ge L., Brewster C., Spek J., Smeenk A., Top J. (2017), Blockchain for Agriculture and Food: Findings from the Pilot Study, Wageningen Economic Research Report 2017-112, http://ictupdate.cta.int/2018/09/04/the-rise-of-blockchain-technology-in-agriculture/ (accessed: 24 November 2019).

Iuon-Chang Lin, Hsuan Shih, Jui-Chun Liu, Yi-Xiang Jie (2018), Food Traceability System Using Blockchain, Proceedings of 79th IASTEM International Conference, Tokyo, Japan, 6th-7th October 2017, August 30, http://www.worldresearchlibrary.org/ up_proc/pdf/1121-151134311859-64.pdf (accessed: 24 November 2019).

Kamilaris A., Prenafeta-Boldú F., Fonts A. (2018), The Rise of Blockchain Technology in Agriculture, http://ictupdate.cta.int/2018/09/04/the-rise-of-blockchain-technologyin-agriculture/ (accessed: 24 November 2019).

Khan M. A., Salah K. (2017), IoT Security: Review, Blockchain Solutions, and Open Challenges, "Future Generation Computer Systems", vol. 82, https://doi.org/10.1016/ j.future.2017.11.022.

Kim H., Laskowski M. (2018), Toward an Ontology-driven Blockchain Design for Supply-chain Provenance, "Intelligent Systems in Accounting, Finance, and Management", vol. 25, no. 1, https://doi.org/10.1002/isaf.1424. 
Lemieux V. L. (2016), Trusting Records: Is Blockchain Technology the Answer?, "Records Management Journal", vol. 26, no. 2, https://doi.org/10.1108/rmj-12-2015-0042.

Prasannan K., Varghese B., Smita C. T. (2019), Evaluation of Supply Chain Management Based on Block Chain Technology and Homomorphism Encryption, "International Journal of Information Systems and Computer Sciences", vol. 8, no 2, https://doi. org/10.30534/ijiscs/2019/15822019.

Ray P., Om Harsh H., Daniel A., Ray A. (2019), Incorporating Block Chain Technology in Food Supply Chain, "International Journal of Management Studies", vol. VI, no 1(5), https://doi.org/10.18843/ijms/v6i1(5)/13.

Swan M. (2015), Blockchain: Blueprint for a New Economy, O’Reilly Media, Sebastopol, CA.

Swan M. (2018), Blockchain: Blueprint for a New Economy, O'Reilly Media, May 21, https://dl.acm.org/citation.cfm?id=3006358 (accessed: 24 November 2019).

Tian F. (2016), An Agri-food Supply Chain Traceability System for China Based on RFID \& Blockchain Technology, 2016 13th International Conference on Service Systems and Service Management (ICSSSM), https://doi.org/10.1109/ICSSSM.2016.7538424.

Tian F. (2017), A Supply Chain Traceability System for Food Safety Based on HACCP, blockchain \& Internet of Things, 2017 International Conference on Service Systems and Service Management, https://doi.org/10.1109/ICSSSM.2017.7996119.

Underwood S. (2016), Blockchain beyond Bitcoin, "Communications of the ACM”, vol. 59, no 11, https://doi.org/10.1145/2994581.

Yu-Pin Lin, Petway J., Anthony J., Mukhtar H., Shih-Wei Liao, Cheng-Fu Chou, Yi-Fong Ho (2017), Blockchain: The Evolutionary Next Step for ICT E-Agriculture, "Environment Journal", vol. 4, no 3, https://doi.org/10.3390/environments4030050.

\section{Wykorzystanie technologii blockchain w rolnictwie (Streszczenie)}

Cel: Celem artykułu jest ukazanie wybranych aspektów wykorzystania technologii blockchain w rolnictwie oraz produkcji i dystrybucji produktów rolnych.

Metodyka badań: Artykuł opracowany został na podstawie analizy krytycznej światowej literatury przedmiotu, dotyczącej problematyki aktualnego zastosowania technologii blockchain w rolnictwie. Założono, że technologia blockchain jest wykorzystywana w sektorze rolnym w celu promowania bezpieczeństwa żywnościowego, zapobiegania oszustwom na rynku żywnościowym oraz weryfikacji pochodzenia i autentyczności produktów rolnych i środków produkcji rolnej.

Wyniki badań: Technologia blockchain pozwala na identyfikowanie w sposób przejrzysty i zrozumiały wszystkich elementów w łańcuchu wartości w rolnictwie, umożliwia wychwytywanie procesów nieoptymalnych oraz rozpoznawanie podmiotów, których intencje można uznać za nieuczciwe. Wykorzystanie technologii blockchain pozwala optymalizować ogólne warunki funkcjonowania rynku produktów żywnościowych oraz monitorować pochodzenie produktów spożywczych, co jest niezbędne w przypadku wystąpienia nieprawidłowości w zakresie bezpieczeństwa żywności. Wczesne rozpoznanie np. źródła zanieczyszczenia produktów spożywczych umożliwia szybkie rozpoczęcie działań niezbędnych do zapobiegania chorobom, a tym samym ratowania życia. Szybka 
reakcja na zauważone nieprawidłowości pomaga również w ograniczaniu marnotrawienia żywności, co pozwala na minimalizowanie strat finansowych.

Wnioski: Technologia blockchain współcześnie wykazuje duży potencjał w zakresie wykorzystania w sektorze rolnym. Dzięki możliwości szczegółowego śledzenia procesu produkcji żywności można ją wykorzystać w obszarze zapewniania bezpieczeństwa żywności. Ze względu na możliwość przechowywania i przesyłania informacji o transakcjach technologia blockchain może być również wykorzystywana w procesie wypłacania dotacji rolnikom, co gwarantuje szeroki dostęp do programów subsydiowania rolnictwa. Ponadto technologia blockchain oferuje rolnikom możliwość internetowego negocjowania cen produktów rolnych, wykorzystania różnych metod płatności oraz wspomaga realizację procesów sprzedaży gruntów i rejestracji zakupów.

Wkład w rozwój dyscypliny: Technologia blockchain stanowi nowe rozwiązanie, możliwe do wykorzystania w sektorze rolnym, który współcześnie zmaga się z ogromnymi wyzwaniami. Pomimo że nie wypracowano spójnych regulacji w zakresie transakcji blockchain, zastosowanie tej technologii w rolnictwie w opinii autora przynosi obiecujące korzyści.

Słowa kluczowe: technologia blockchain, rolnictwo, oszustwa na rynku żywnościowym, bezpieczeństwo żywności. 